page 1

\title{
EXPERIMENTAL SOCIOECOLOGY: INTEGRATIVE SCIENCE FOR ANTHROPOCENE LANDSCAPE DYNAMICS
}

\begin{abstract}
The emergence of coupled natural and human landscapes marked a transformative interval in the human past that set our species on the road to the urbanized, industrial world in which we live, and enabled technologies and social institutions responsible for human-natural couplings in domains beyond rural, agricultural settings. The Mediterranean Landscape Dynamics Project (MedLand) is studying the interacting social and biophysical processes associated with these novel socioecological systems and their long-term consequences using a new form of 'experimental socioecology' made possible by recent advances in computation. We briefly describe the MedLand modeling laboratory, a hybrid simulation environment that couples models of small-holder farming and herding, landscape evolution, and vegetation change managed through an interaction model. We then review three examples of experimental socioecology carried out in this laboratory. These offer new insights for scale-dependent thresholds in agropastoral productivity, long-term sustainability of alternative land-use strategies, and identifying signatures of human and climate-driven landscape dynamics. We conclude with an overview of new directions for this interdisciplinary research on Anthropocene human-earth systems, including: modeling more diverse decision-making strategies for land-use, developing more sophisticated models of vegetation dynamics and fire ecology, and generating digital proxy data for more robust model validation against the empirical record.
\end{abstract}

\section{Introduction}

A travel brochure for the Mediterranean might portray a landscape of fertile plains and rocky coasts, backed by rugged mountains; a place of ancient cities and picturesque villages, perched amid terraced hillsides; a rural countryside with fields of wheat and barley and stands of olives, almonds, and fruit trees; where the rich heritage of past civilizations can be seen in abundant monuments and ruins. The same region also could be described through different lenses as a degraded landscape of denuded mountains and eroded ravines that has suffered repeated deforestation, where sediments from upland erosion have buried coastal plains and filled harbors, where soils are exhausted and plant communities are ravaged from over-grazing, and where thousands of years of human occupation have left no patch of the original, natural environment. The Mediterranean is one of the world's oldest coupled natural and human systems, the place 
where humans transformed themselves from harvesters of wild plants and animals to managers of complex socio-ecological systems (SES) (Simmons, 2007). An exemplar of the complex interactions between human and earth systems that characterize the Anthropocene, some parts of the Mediterranean have suffered serious declines in productivity, but many other portions - and especially the western Mediterranean (bordering Spain, France, and Italy in Europe)—have maintained productive rural landscapes that have supported dense urban populations for millennia. In many respects, the western Mediterranean embodies fundamental questions of sustainability and its paradoxes: How can the earth sustain a human population rapidly growing toward 10 billion and not only maintain human life, but also quality of life? In seeking such a goal, how can we successfully manage a continually changing landscape that is driven by interacting human and natural forces, and perceived through different cultural lenses as both beauty and degradation? We are endeavoring to contribute answers to such questions though research on the origins of coupled natural and human landscapes in the western Mediterranean. A better understanding of how social and biophysical systems became so closely coupled, and the cascade of consequences from this coupling, can help us better anticipate the impacts of the global coupling of SES that we face in the world today.

\section{The Emergence of Coupled Natural and Human Systems}

Archaeologists have long proposed that the transition from hunter/gatherer to farmer was the result of feedbacks that involved changing productivity of domesticates, decrease in time allocated to hunting and gathering, displacement of wild resources, new patterns of subsistence risk and uncertainty, and changes in landscapes (Braidwood et al., 1983; Flannery, 1986; Fuller et al., 2012; Ullah et al., 2015; Vigne, 2011). These feedbacks led to an increasingly close coevolution of the social and natural worlds, in which alterations of landscapes resulting from human decisions in turn influenced changes in social organization, wealth, power, 
technology...and abilities to manage and alter landscapes. As Rindos (1980) pointed out, it was not the domestication of plants and animals per se, but changes in relationships between humans and the natural world that have had the greatest impacts on human societies.

The modern Mediterranean basin exemplifies the complex coupling of natural and human landscapes in an SES; people have not simply replaced the natural environment with an artificial one. Rather, much of the landscape change in this region, especially in rural areas, has come about through anthropogenic rearrangement of biophysical components. Many of the cereal grasses, legumes, and tree crops that characterize Mediterranean agriculture were components of its early Holocene woodlands, as were the many common domestic animals. Pine/oak/juniper woodlands with scattered olives, almonds, and pistachios, and stands of cereal grasses, legumes, and herbs in clearings have been rearranged into fields of cereals and legumes (Figure 1a); hillslopes and kitchen gardens of herbs; and 'woodlands' of olive, almond, and pistachio orchards interspersed with scattered pines, oaks, and junipers along field borders, around houses, and on upper slopes. Sheep, cattle, and goats still graze in these rearranged plant communities, as they did when people hunted them instead of herding them (Figure 1b). Sediments released by vegetation clearance have been relocated via water transport from upland slopes to extend coastal plains into new fields and pastures, or have been captured or transported anthropologically onto slopes and secured by terrace walls instead of plant roots.

This rearrangement of landscape components has both social and biophysical consequences. Human land-use decisions are predicated to an important degree on the spatial arrangement of biophysical features of landscapes: the placement of suitable soils on surfaces of suitable slopes for cultivation, and the placement of sufficiently nutritious plant cover for grazing within walking distance (especially for pre-industrial societies that are the focus of our research, but distance is still important today). Such decisions are also determined in part by human- 
constructed landscape features like terraces (that can hold suitable soils with suitable slopes); storage and processing facilities (e.g., threshing floors, grain silos, milling facilities); and animal corrals and barns sufficiently close to fields, pastures, and dwellings.

Biophysical processes are likewise altered by anthropogenic rearrangement of landscapes. One significant effect is changes to biodiversity at multiple scales. Many of the plants and animals found throughout the Mediterranean region today were originally distributed in a patchwork of local ecosystems. Anthropogenic rearrangement extended the ranges of these organisms across the entire Mediterranean, and in many cases throughout the world. For example, the wild ancestors of wheat, barley, sheep, goats, olives, and lentils lived in a mosaic of small-scale, non- or partly-overlapping habitats. They now co-occur throughout the Mediterranean Basin and have become components of human managed ecosystems across the world (Figure 1). As a result, biodiversity may be decreased at the scale of single fields, compared to the pre-agricultural woodland communities. But it is increased at meso-scales, where many plants and animals that once occupied distinct habitats now co-occur, and there is greater homogenization at the scale of the entire Mediterranean Basin.

Terrestrial surface processes and associated landforms were reorganized in other ways. Replacement of woodland by bare soil, bare soil by crops, and crops by weedy or woody fallow fields alters the susceptibility of surface sediments to erosion (Figure 2). Physical alterations such as soil loosening through cultivation, compaction through trampling, and slope changes due to terracing affect the location and intensity of water-mediated surface dynamics. Soil formation can be retarded through sheet erosion, burial of the surface by upslope mineral sediments, or nutrient depletion from cultivation and grazing. It can also be accelerated by the addition of nutrients (e.g., manuring), aeration from cultivation, or by thickening due to redeposition of upslope organic sediments. Grazing and anthropogenic burning can alter plant succession 
dynamics, which in turn affect soil chemistry, and erosion risk, while orchards and terracing can mitigate these impacts by helping to stabilize slopes and soils (Figure 2).

These changes in biophysical processes in turn influence human land-use decisions, with consequences that can cascade over years, decades, and centuries. These interactions can occur as positive feedbacks between social and biophysical drivers that accelerate rates of landscape change, as negative feedbacks that can maintain landscape and social stability, or as path dependencies that can lock in land-use practices and make it difficult for societies to adapt to exogenous environmental changes like those due to climate.

Understanding the causes and consequences of these long-term interactions between human and natural forces is an important key to the questions of sustainability raised previously. However, the complex nature of both social and ecological systems, and the even more complex interactions between human and natural systems severely limit our capacity to intuit the causes of change and consequences of human action, and reductionist analytical approaches designed to isolate linear cause and effect relationships are often ineffective (Dawson et al., 2010). These inherent difficulties in studying Anthropocene earth systems are further exacerbated by the need to track these dynamics over time frames much longer than can be observed directly.

These issues of non-linear causality and long time-scales have made quantitative, processbased modeling especially important for scientific study of Anthropocene SES (Kelly Letcher et al., 2013; Rounsevell et al., 2014; Verburg et al., in press). Model-based science provides tools for exploration and analysis of the multi-dimensional, non-linear, and often counter-intuitive interactions between social and biophysical processes that drive Anthropocene earth systems. Modeling environments can be used as virtual laboratories to study how system dynamics can play out over long-time spans (Bankes et al., 2002; van der Leeuw, 2004). They enable the testing of hypotheses and the assessment of the significance of controlling parameters and 
processes in resulting forms and interactions. Of equal importance, experiments can be designed in these modeling laboratories to examine counter-factual histories or future scenarios. This is essential for systematically testing hypotheses about the consequences of varying social or biophysical drivers in complex SES — even though they did not happen in the real past or have not yet happened in the present. We need model-based science if we hope to effectively manage the coupled human and natural systems that have expanded to global scales in today's world.

Our research in the Mediterranean is helping to develop and test model-based research protocols for SES. It combines computational modeling of the interacting social and biophysical processes that drive long-term landscape dynamics with empirical studies in the social and natural sciences. In this paper, we present a brief overview of this integrative approach and some examples of modeling research into the coupled human and natural systems that define the Anthropocene.

\section{The Mediterranean Landscape Dynamics Project}

The Mediterranean Landscape Dynamics (MedLand) project was begun in 2004 to develop a computational laboratory for quantitative modeling of land-use/landscape interaction dynamics, supported by empirical fieldwork in the social and natural sciences. This work adds new computational approaches to a long and rich history of prior empirical research on prehistoric human societies and past ecosystems across the Mediterranean region. The MedLand Modeling Laboratory (MML) integrates several different types of models that are dynamically coupled to permit high-resolution, realistic simulation of socio-ecological system dynamics.

As with real-world SES, simulating the interactions between human activities and landscape processes creates model and computational complexities that can multiply rapidly. Organizing the MML as modular, composable, heterogeneous components helps to manage overall model complexity (Davis and Anderson, 2004, p. 200; Sarjoughian, 2006). This approach has been 
shown to facilitate the creation and use of heterogeneous simulation models that remain computationally efficient while the number of model components and the frequency of their interactions increase, potentially by a few orders of magnitude (Gholami et al., 2014; Sarjoughian et al., 2013).

The main components coupled in the MML include an agent-based model (ABM) of households practicing subsistence agriculture and/or pastoralism, a cellular automata landscape evolution model (LEM), an associated model of vegetation change, and an interaction model that manages the dynamic couplings between the ABM and LEM. Paleoclimate models run independently, with their results input as parameters to the LEM (Barton et al., 2012, 2010b; Mayer and Sarjoughian, 2009; Mitasova et al., 2013; Soto-Berelov, 2011). We discuss these components in more detail below.

Several different platforms are used for the ABM component. As with the LEM, described below, some agent based simulation has been developed combining the Python programming language and raster (i.e., cellular) processing modules of GRASS GIS (Neteler et al., 2012; Neteler and Mitasova, 2008). More complex decision and land-use algorithms for agents have been written in DEVS (Discrete-Event System Specification) Suite (http://acims.asu.edu/software/devs-suite/; Kim et al., 2009) and Repast (North et al., 2013, 2007). All platforms used for modeling are open-source to make them widely accessible to others, and to ensure transparency in the computational algorithms used and program structure.

Selecting households as the base agent in an ABM for simulating land-use decisions and practice mirrors the organization of known small-scale subsistence farmers (Banning, 2010; Flannery, 1993; Kohler and van der Leeuw, 2007). Household agents select patches of land needed for fields and pasture, using decision algorithms informed by past farming and herding experience, household food and fuel needs, the relative importance of plant cultivation versus 
animal herding and perception of potential patch productivity (Mayer et al., 2006). Published studies of subsistence farming — with emphasis on the Mediterranean and xeric landscapesparameterize land-use practices in the MML, including the way land is assessed and land-use decisions made, and the caloric returns from common Mediterranean domesticates (cereals, legumes, ovicaprines, cattle, pigs) (Al-Jaloudy, 2006; Araus et al., 1997; Corbeels et al., 2000; Gibbon, 1981; Hillman, 1973; Hirata et al., 1998; Kamp, 2000, 1987, p. 1987; Khresat et al., 2008, 1998; Kramer, 1982, 1980; Nyerges, 1980; Stuth and Sheffield, 1991; Thomson, 1987; Thomson et al., 1986; Ullah, 2013, 2011; Watson, 1979). Because of our focus on the initial emergence of coupled natural and human landscapes, we have emphasized modeling the first nutritionally significant domesticates in the Mediterranean region-cereal grasses (primarily wheat and barley) and ovicaprines (sheep and goats). However, adding other plants and animals (e.g., legumes, tree crops, cattle, pigs) that became increasingly important with greater human dependence on managed ecosystems could be accomplished with minor changes to the software.

The LEM also is written in Python to use fast raster processing modules and map algebra capabilities of the GRASS GIS geospatial modeling environment (Mitasova et al., 2013). It iteratively evolves digital landscapes by simulating soil creep, overland flow, rill and gully formation, and channel flow of moderate scale in order to calculate sediment entrainment, transport, and deposition. The model activates underlying process equations as a function of overland flow accumulation and topography, including a 3D implementation of the Unit Stream Power Erosion/Deposition (USPED) equation to simulate transport capacity on hillslopes and rills, and the Stream Power equation to represent transport capacity in channels; soil creep and reach-averaged shear stress also can optionally be used if desired (Foster and Meyer, 1971; Mitas and Mitasova, 1998; Mitasova et al., 2013, 1996; Moore and Burch, 1986; Tucker and Bradley, 2010). The LEM calculates divergence in sediment transport capacity from one cell to the next, 
as water flows across a landscape, to estimate erosion (increase in transport capacity) or deposition (decrease in transport capacity) in each cell. The net erosion or deposition in each cell is then added to the digital surface (i.e., DEM) to raise or lower it accordingly at each cell; these processes are iterated over multiple, annual time-steps to simulate three-dimensional landscape evolution. As well as soil fertility, the LEM also tracks soil fertility, which can decrease with longer and/or more intensive cultivation and increase with fallowing. A simple vegetation model is embedded in the LEM, in which vegetation can be removed for cultivation or by grazing and regrows, increasing resistance to erosion, following a logistic grow curve scaled to a 50-year succession interval based on empirical studies in the region (Bonet, 2004; Bonet and Pausas, 2007). As we discuss below, enhancements to the MML in development include a more sophisticated vegetation model.

The interaction model (IM) serves to dynamically couple the ABM and LEM components of the MML, capturing computational properties of human/landscape interactions that do not belong entirely to either ABM nor LEM (Sarjoughian et al., 2015). This reduces ABM and LEM model complexities by maintaining the independence of models and their execution environment. The IM approach also facilitates synchronizing and executing the ABM and LEM models, helping to reduce the amount of time needed to run simulation experiments.

The goal of our research is not to "digitally reconstruct" ancient societies and their environments, but to study the evolution of dynamic interactions between land-use and landscapes in the Anthropocene. The MML was designed as an environment in which to create quantitative models of landscape evolution and human land-use, and then systematically vary initial conditions and modeled processes in a controlled, experimental environment (Bankes et al., 2002; Miller and Page, 2007; van der Leeuw, 2004; Verburg et al., in press). We employ the empirical anthropological, archaeological, and paleoecological records for parameterizing and 
validating models, rather than as a basis for inferring the past. We have used the MML to carry out a series of computational experiments in long-term Anthropocene system dynamics, and briefly summarize several of these below. They serve to illustrate the potential of quantitative modeling to contribute to a better understanding of the dynamics of coupled human and natural earth systems.

\section{Scale-dependent thresholds}

One of the first set of experiments carried out in the MML identified scale-dependent thresholds in the consequences of small-holder agropastoral land-use (Barton et al., 2010a, 2010b). The simulations were situated in an environment based on the mid-Holocene landscape and archaeology of northern Jordan (Banning, 2007, 1996; Ullah, 2011), in the catchment of the Wadi Ziqlab (Figures 3 and 4). Several parameters of the modeling environment were varied. Simulated land-use was modeled for an equivalent of two generations (40 years) in the context of communities based on different sized prehistoric Neolithic sites: a farming hamlet of about five households and a small village of about 20 households. Occupants of these communities engaged in intensive horticulture (i.e., repeated use of fields near the settlement) or shifting (or swidden) cultivation (i.e., fields were used for several years and then left fallow and new fields cleared), with or without sheep and goat grazing in the surrounding countryside (Figure 4). Grazing and farming catchment configurations were determined using the method outlined by Ullah (2011), such that the size and configuration of pastoral and agricultural catchments were determined using a ratio of people to sheep and goats of 20 and a per capita amount of farmland of 1.36 ha.

Experiments carried out on the same landscape without any human activity allowed us to establish a baseline from which to calculate the net anthropogenic effects of these different demographic and land-use scenarios. As noted above, the ability to represent such contrafactual ecological dynamics (i.e., a Holocene world without humans) is a little discussed but uniquely 
important contribution of this kind of modeling that is impossible with the analysis of prehistoric empirical data alone. Not only does this provide a more comprehensive understanding of the response of SES to changes in different social and biophysical parameters than can be achieved through study of empirical data (i.e., what could happen, rather than only what did happen), but it also provides insight into the relative contribution of human and natural processes to Anthropocene landscape dynamics.

In these experiments, human land-use had impacts on the landscape in the form of erosion of sediment in some places and sediment accumulation in others. Some of the most interesting results emerged from comparison of the consequences of community size in the land-use scenarios with the greatest anthropogenic impacts (shifting cultivation combined with ovicaprine grazing) (Figure 5). Below a community size threshold, sediment accumulation in locations that enhanced economic productivity balanced erosion in places that did not adversely impact productivity. However, if a community following the same land-use practices exceeded this threshold, the system experienced a phase change in which loss of productive land due to erosion greatly exceeded beneficial effects of sediment accumulation. The exact threshold at which this phase change occurs is likely dependent on local biogeophysical conditions; in the digital environment of our experiments it was represented by the difference in population between a tiny farming hamlet of around 20 people and a small village of around 100 persons. A longer simulation run suggests that these disparities are most marked within the first century after population increase, and then ameliorate somewhat over the subsequent century (Barton et al., 2010b figure 7).

These results have implications for a noted pattern of human population growth and socioecological change (the "Neolithic Demographic Transition") that occurred in many places during the initial emergence of human-managed ecosystems (Bocquet-Appel, 2009). In southwest Asia, 
for example, archaeologists have noted a period of expansion and growth in the size of human communities after the initial transition from hunting and gathering to agriculture (Guerrero et al., 2008). This was followed by the abandonment of many of the large towns and dispersal of population into small settlements (Kuijt, 2000). A subsequent reorganization of land-use and associated technology (e.g., farming of more diverse locales, use of animal-drawn plows, specialized pastoralism, the use of 'secondary' animal products like milk and wool) then drove a second expansion in human managed socio-ecosystems and demographic changes accompanied by the first appearance of urbanism (Quintero et al., 2004; Rosen, 2008; Sherratt, 1983; Simmons, 2007; Twiss, 2007). Similar trends have been noted for the initial farming economies across Europe (McClure et al., 2009; Shennan et al., 2013) and China (Bellwood and Oxenham, 2008; Pechenkina et al., 2002). The modeling approach exemplified here allows us to more fully investigate these non-linear changes in Anthropocene SES that initiated the trajectory in subsequent centuries towards the densely populated, urbanized, anthropogenic world of today.

\section{Long-term sustainability in land-use strategies}

Another set of experiments focused on other impacts of different land-use and decision strategies on landscapes and long-term human demography (Ullah, 2013). In different simulation runs (Figure 6), household agents of a community could specialize in agriculture (80\% of their calories obtained from plant cultivation and $20 \%$ from domestic animals), pastoralism (20\% of calories obtained from plant cultivation and $80 \%$ from domestic animals), or balanced agropastoralism (50\% of calories obtained from plant cultivation and 50\% from domestic animals). This yielded herd sizes ranging from 7 animals per capita (agricultural strategy) to 26 animals per capita (pastoral strategy). Agent communities could also emphasize different landuse decision strategies. 'Hardworking' agents searched for the best land, regardless of the labor needed to clear and prepare it, while 'lazy' agents preferred land that had already been cleared or 
regrown only to shrub-land (maqui/matorral) after fallowing. The farming strategy of 'Greedy' agents affected the fertility of land more intensely (2\% versus $1 \%$ fertility decline per year) and maintained herds at twice the density per hectare ( 0.3 versus 0.15 animals per hectare) as was maintained by 'good' agents. Again, these simulation experiments were situated in a virtual world based on the mid-Holocene Neolithic farmers of northern Jordan (Figures 3 and 4).

One of the more notable results of this set of experiments might help to explain the bifurcation of ecosystem management in the Anthropocene into agriculturalists who specialize in plant cultivation on the one hand, and pastoralists who specialize in stock-raising on the other. Although agriculturalists may keep a modest number of domesticated animals, and pastoralists may engage in plant cultivation to a limited degree, there are very few societies in which households place equal emphasis on plant cultivation and animal herding (Ullah et al., 2015). In repeated modeling runs of 500 simulated years, communities emphasizing plant agriculture grew to a meta-stable equilibrium level around which population varied (Figure 6). Pastoralists experienced repeated cycles of growth and population collapse, alternating between two population size attractors, but at levels much lower than those of agriculturalists. Balanced agropastoralist agent populations grew slowly, sometimes exceeding pastoralist populations, but never reaching the level of agriculturalists. However, agropastoral populations experienced large boom/bust cycles, especially if they tried to maximize agropastoral returns (i.e., 'greedy' strategists). Over longer time spans, agropastoralist populations often could not recover from these larger 'bust' cycles. The findings showed that in the short-term, all mixes of plant cultivation and animal herding are equally viable. But over the long term, land-use that emphasizes either agriculture or pastoralism may outcompete a seemingly "balanced" strategy of equal parts agriculture and pastoralism. That is, there are inherent trade-offs between agriculture and pastoralism that eventually require either wholesale bifurcation of the two subsistence 
pursuits, or larger-scale social management of agricultural and pastoral practices. This insight recently received additional empirical support from a global study of human subsistence practices in the present and recent past (Ullah et al., 2015).

\section{Signatures of human and non-human landscape change}

Many Mediterranean landscapes have experienced two broad classes of surface change: 1) areally extensive erosion resulting in soil loss, bedrock exposure, along with accumulation of eroded soils and sediments in valleys and channels, and 2) incision (sometimes very deep) of gullies and intermittent drainages, like wadis and barrancos. We examined the first of these two types of surface change in the earlier modeling examples described above. In our most recent set of experiments, we focused on understanding the second class of surface change. Specifically, we investigated the relative impacts of anthropogenic changes to vegetation on the incision of barrancos vs. extensive hillslope erosion (Barton et al., 2015).

We situated these experiments in a virtual environment modeled on the landscapes of centraleastern Spain (Figures 3 and 7). This is a region characterized by numerous, deeply incised barrancos (Figure 2). While this incision is generally thought to be a consequence of human activity in the latter half of the Holocene, direct observation of modern gullying cannot provide empirical data on the effects of human land-use on incision dynamics over the span of centuries to millennia (Bintliff, 2002; Gutiérrez et al., 2009; Hooke, 2006; Marzolff et al., 2011; Nogueras et al., 2000). In order to model human impacts on incision, we first had to 'restore' the virtual landscape to a pre-incised state. This involved digitally filling Holocene-incised barrancos in a watershed basin (Rio Penaguila valley, northern Alicante Province) using spatial interpolation techniques (Barton et al., 2015). All simulation experiments were initiated in this restored virtual landscape of the Penaguila basin (Figures3 and 7). 
All simulation runs extended for 300 years. Two sets of modeling experiments were run without human presence. In one of these simulations of non-human ecosystem change, landscape dynamics were modeled in a Mediterranean woodland environment, similar to the preagricultural Holocene vegetation of this region, based on paleoenvironmental proxy data (Badal et al., 1994; Carrión et al., 2010). The second set of experiments without people ran in an environment denuded of woodland and covered with the equivalent of sparse grassland, representing vegetation change from the 'pristine' Holocene condition due to non-anthropogenic causes, such as climate change. Six sets of experiments with human land-use also were carried out. A single farming village was situated in the basin at the location of the early Neolithic farming site of Mas d'Is (Bernabeu Auban et al., 2008, 2003) with a population of 30, 60, and 120 inhabitants. For each population scenario, the community agents could adopt a satisficing or a maximizing strategy for choosing land. All communities were comprised of 'agriculturalist' agents as defined above, with $80 \%$ of caloric needs met by plants and $20 \%$ by animal products. With a satisficing strategy, a community would select land to farm and graze until caloric needs were met. It would continue to use this land unless it was unable to produce enough to satisfy caloric needs, in which case the worst producing fields were abandoned and new fields chosen from the surrounding area. For a maximizing strategy, the community would drop any underperforming fields and choose new ones every year. Not surprisingly, maximizing strategies practiced by larger communities tend to lead to more active surface processes of erosion and deposition than satisficing strategies in small communities; likewise, surface processes without human presence are more energetic in denuded landscapes than they are in wooded ones (Figure 8). Unexpectedly, however, the results of these experiments suggest very different erosional signatures for anthropogenic and non-anthropogenic drivers of long-term dynamics of landscape change (Figure 8). Compared with the preagricultural, wooded, Holocene landscape, non- 
anthropogenic denudation results in a large increase in the amount of sediment lost from erosion of hillslopes, swales, and other surfaces outside the barrancos, and an even larger increase in the amount of sediment deposited in barranco channels. But non-anthropogenic vegetation change generates modest amounts of sediment accumulation on non-barranco surfaces, and minimal incision in barranco channels. Shifting cultivation and grazing, on the other hand, leads to modest increases over unpopulated wooded landscapes in hillslope erosion and sediment accumulation on non-barranco surfaces, considerably less than non-anthropogenic denudation in both cases. But agropastoral land-use results in very large increases in sediment transport in barranco channels, with both erosion (in some areas) and deposition (in other areas) exceeding the effects of non-anthropogenic denudation by orders of magnitude. As in the first example discussed above, larger populations are associated with more incision and less redeposition in these channels, and smaller populations with less incision and more sediment accumulation.

Although climate parameters were not varied in these experiments, the results match the dynamics proposed by McClure and colleagues (McClure et al., 2009) on the basis of archaeological data for the reorganization of early farming societies and practices in this region of Spain. Importantly, if these results are supported by further modeling experiments and empirical testing currently planned, they offer a way to differentiate human and non-human (e.g. climate) drivers of landscape change in the evolution of Anthropocene landscapes. They also have the potential to help to better identify potential vulnerabilities to agropastoral practice and climate change in modern agropastoral systems.

\section{Future enhancements to the MML}

While the modular, experimentation-oriented environment of the current MML has produced valuable insights about the dynamics of coupled human-biophysical systems and comparisons with the empirical record, this work has also shown us ways in which the MedLand laboratory 
could be extended and enhanced. We are now recomposing portions of the core MML environment to better support a wider range of research into long-term dynamics of coupled human and natural landscapes, and improve our abilities to validate model results with the empirical record.

One enhancement is to increase the diversity of decision strategies that can be represented in the farming household component of the MML. Initially, our households useda "satisficing" strategy, which attempts to minimize production costs while ensuring sufficient returns. This can also represent the combined effects of attempting to optimize diverse goals in which farming/herding returns are only one component. Building on the work summarized in the second and third modeling examples described above, we have begun to also implement decision strategies that attempt to maximize net returns from land-use. Maximizing is an agent decisionmaking approach widely assumed in many economic and evolutionary models. Both maximizing and satisficing/multi-factor-optimizing decisions assume that an individual evaluates costs and returns of different actions directly. However, such direct evaluation also comes with a substantial risk of testing subsistence practices that turn out to be sub-optimal or insufficient to maintain a household. Other decision strategies can allow agents to avoid such risks (Boyd and Richerson, 1985; Henrich and Henrich, 2007; Rendell et al., 2010). For example, an agent may choose to copy the strategy of the most successful agent in a community rather than evaluate alternative strategies directly. A drawback to this approach is the difficulty in clearly ascertaining the relative success of others, especially over short time spans. Another decision strategy avoids such complications by allowing an agent to simply follow the strategy of the majority of community members. We are adding these additional strategies to our agents' repertoire of decision logics, and enhancing the modeling architecture to allow multiple types of decision logic to be used in a single simulation. 
Another area of major change in the ABM component of the MML involves extending the flexibility of household and community demographic processes. The current agent models were developed with no rules for dynamically changing community locations or the number of households during a simulation. This has limited our earlier experiments to models involving sedentary communities. Modification of the way we model households will allow them to die/dissolve or to spawn new descendent households in response to the economic success or failure of land-use/landscape interactions. In this way, simulated communities can not only grow or decline in the size of each household (as is the case now), but also in the total number of households that make up the community. It is important for the MML to be able to implement both of these kinds of community-level demographic changes, as they may have different effects on long-term socio-ecological processes: one changes the number of decision-making agents (i.e., numbers of households) while the other does not. We are also adding the capacity for households to 'own' patches of land across multiple simulation years, rather than choose land at every cycle, creating the potential for wealth differences among households. Together, these enhancements permit more socially nuanced experiments on the feedbacks between social decision-making and environmental change.

We also plan enhancements to the LEM component of the MML to better manage the large and complex data it produces and to improve the ability to validate model results with the empirical record of social and environmental change in the Anthropocene (Verburg et al., in press). A powerful way to validate complex models of socio-ecological systems is to test their ability to generate model output that is similar to the empirical record of known historical cases - a procedure followed by many earth systems models today (Braconnot et al., 2012). Currently, the MML produces spatially-explicit, digital representations of important components of socio-natural landscapes, such as sediment supply, sediment movement, soil fertility, and 
surface vegetation. It is necessary to compare these model outputs with the archaeological and paleoecological proxy record if the ability of the model to simulate long-term dynamics of these systems is to be properly validated. But most proxy data for past landscape change is derived from sediment samples (from natural or artificial exposures, or cores), archaeological excavations (including archaeological coring and geophysical survey), and systematic collection of artifacts exposed on land surfaces. While artifacts can serve as a proxy for human land-use, phytoliths from sediment samples (silica microskeletons of plants) can provide a proxy for vegetation cover (Elliott et al., 2010), and cosmogenic isotopes (also from sediment samples) can serve to estimate millennial-scale erosion rates (Granger et al., 2013),. The profound differences in the spatial and temporal structures of model output and the empirical data collected for the proxy record make model validation challenging.

To help mitigate these issues, we are enhancing the LEM to generate 'virtual proxy data' that will be more comparable to empirical paleoecological data. In each model cycle, the LEM will generate 'virtual artifacts' in proportion to human activity and settlement in each model landscape cell, it will generate 'virtual phytoliths' for the plant communities in each cell, and it will generate 'virtual isotopes' whose counters can increment or decrement depending on which isotope is modeled. The ability of the LEM to simulate erosion and deposition make it possible to digitally 'bury' some of these virtual proxy data through simulated sediment deposition, leave some exposed at the surface, and eliminate others due to loss by erosion. To better manage the more complex geospatial datasets generated by adding virtual proxy data, we are using the new "temporal GIS" capabilities in GRASS to generate cumulative space-time cubes of model output. Temporal GIS offers superior management of the kinds of 3D time-series information generated by spatially explicit models like the MML. The switch from a series of sequential 2D maps to integrated space-time cubes will allow the LEM to build a cumulative digital representation of 
the underlying stratigraphy beneath an evolving digital surface (see analogous modeling in Clevis et al., 2006).

Finally, we are creating a more sophisticated process model for vegetation using a simplified individual-based model or gap model approach. Instead of species, we simulate plant functional types based on responses to fire-including fire tolerance, resprouting, and fire-stimulated recruitment (Pausas, 2006, 1999)—and plant life forms (e.g., tree and shrub). This representation of vegetation cover is combined computationally with terrain parameters from the LEM and the potential for anthropogenic fire from the ABM to output vegetation state maps that feed back into the $\mathrm{ABM}$ (affecting land-use decisions) and as land-cover characteristics in the LEM (affecting erosion potential). The enhanced vegetation model is coded in Python to interact with raster processing modules of GRASS GIS.

\section{Discussion}

The emergence of coupled natural and human landscapes marked a transformative interval in the human past that set our species on the road to the urbanized, industrial world in which we live - a life far different from that of other animals on this planet. The shift by humans from consumers to managers of rural landscapes ultimately underpins and enables many of the technologies and social institutions responsible for human-natural couplings in other domains. Our socioeconomic system today is still supported by a food supply made possible because of the emergence of coupled human and natural systems in rural landscapes, underscoring the value of a better understanding of their dynamics in the past, present, and future. And while industrial agriculture is increasingly prevalent, a very large proportion of humanity still lives in small, rural communities and practices subsistence farming and herding quite similar to that of the western Mediterranean SES in the mid-Holocene. 
The integrated modeling and empirical science of the MedLand project has the potential to offer new insights into the prehistoric origins of human-environmental interactions that characterize the Anthropocene. However, our research seeks to generate new insights on the interactions and long-term dynamics of these coupled systems more generally rather than simply create a digital reconstruction of the human past. To this end, although we are ensuring that our modeling systems can output results that are comparable to real cases studies, as a way to evaluate the ability of MML algorithms to simulate real-world processes, they are not constrained by empirical data from also generating results that are contra-factual. This distinction is extremely important. The realized past is but one of many possible socio-ecological trajectories. Our modeling framework needs to be flexible enough to show us other possible outcomes of the same dynamics that made the empirical proxy record of the past and could shape the unrealized world of our future.

We do not expect that simple analogies between emergent coupled human and natural systems from thousands of years in the past translate directly into better land-use decisionmaking today. The mid-Holocene and the twenty-first century manifest vastly different scales at which, population sizes, social complexity, and energy sources can be leveraged to transform landscapes. Yet the processes associated with the emergence of coupled natural and human landscapes are 'ancestral' to those that drive the coupled natural and human systems that dominate the modern world. Moreover, disentangling the complex network of interactions linking the social and natural worlds can be more straightforward with the initial couplings of ancient SES than with their modern descendants that are the result of millennia of cumulative changes and co-evolution. And we must look at the past in order to understand the long-term effects of different decision, practices, and biophysical dynamics as these cumulatively build on each other in complex ways. This will help us develop better theory to account for the dynamics 
of these hybrid systems. In this sense, the modeling experiments that we are carrying out serve as hypotheses about Anthropocene SES dynamics that we test against the record of the long-term past.

The research described here exemplifies a new form of 'experimental socioecology' that has been made possible by recent advances in cyberinfrastructure and computing technologies. The methodologies that we are developing and applying — along with the parallel work of othersopens a door to a transformation of social science that can give it a more central role in interdisciplinary research on the grand challenges (nearly all of which are human challenges) that we face today. Innovative computationally-enabled methodologies, new integrative theory of social dynamics, and a renewed long-term perspective are all needed for future research to develop more sustainable solutions to these challenges.

\section{Acknowledgements}

This research has been made possible by the US National Science Foundation (grants BCS410269 and DEB-1313727), and support from Arizona State University and the Universitat de València, Spain. Fieldwork in the Jordanian project region was conducted under the Wadi Ziqlab Project, with multiple grants from the Social Sciences and Humanities Research Council of Canada and support from the University of Toronto. A special thanks to E.B. Banning for providing addi-tional field data from the Wadi Ziqlab project and to Mariela Soto-Berelov for providing paleovegetation data in the Wadi Ziqlab area. Many other people in Jordan, Spain, and the US contributed in various ways to these multiple project and we want to extend our thanks to them also. Photo credits in graphical abstract: Michael Barton and Isaac Ullah, 2015. 


\section{Figure Captions}

Figure 1. Coupled natural and human landscapes in the Mediterranean: a) wheat field and b) goat herd in northern Jordan. Photos by Isaac Ullah.

Figure 2. Terraced olive grove and barranco erosion in eastern Spain. Photo by Michael Barton.

Figure 3. Watersheds of the Wadi Ziqlab, Jordan, and Rio Penaguila, Spain (color-shaded areas in relief maps maps) and their locations in the Mediterranean Basin.

Figure 4. Catchments for modeling swidden cereal agriculture and ovicaprine grazing for a farming hamlet and a small village (yellow triangles) in the Wadi Ziqlab (Jordan). Areas around each community used for cereal cultivation are colored dark blue, and the larger grazing catchments are shaded light green.

Figure 5. Cumulative, anthropogenic erosion and deposition in the Wadi Ziqlab (Jordan) watershed over 40 years of simulated shifting cultivation and grazing around a farming hamlet and a small village.

Cumulative deposition is shown in the upper graph and cumulative erosion is shown in the lower graph. Erosion and deposition are shown separately because they have different consequences for land-use and often occur in different parts of the landscape (see text). Shading represents one standard deviation around the central mean line for multiple simulation runs with the same initial parameter values.

Figure 6. Simulated populations of a small village of agriculturalists, of pastoralists, and balanced agropastoralists (see text), as they change over 500 years in response to economic returns from farming and herding in the Wadi Ziqlab (Jordan). The shaded zones represent the 95\% confidence interval around mean line of multiple simulation runs with the same initial parameter values.

Figure 7. Simulated cumulative landscape change in the Rio Penaguila (Spain) watershed after 300 years of farming and grazing by a village of 120 people using a maximizing strategy of land-use (see text). Image shows a portion of the Rio Penaguila watershed with colors indicating meters of erosion and deposition on hillslopes and in a barranco channel (outlined in black for clarity). Village location is indicated by black dot, and the farming catchment is shown by light red shading. Modeled grazing took place throughout this small watershed, including on fallowed fields.

Figure 8. Cumulative erosion and deposition modeled for the Rio Penaguila (Spain) watershed. Shading represents one standard deviation around the central mean line for multiple simulation runs with the same initial parameter values. Erosion and deposition in barranco channels (left) is separated from erosion/deposition on hillslopes (right) for comparison. 


\section{References Cited}

Al-Jaloudy, M.A., 2006. Country Pasture/Forage Resource Profiles: Jordan [WWW Document]. Food and Agriculture Organization of the United Nations Country Pasture Profiles. URL http://www.fao.org/ag/AGP/agpc/doc/Counprof/Jordan/Jordan.htm\#4.\%20RUMINANT\%20LIV ESTOCK\%20PRODUCTION\%20SYSTEMS (accessed 5.13.10).

Araus, J.L., Amaro, T., Zuhair, Y., Nachit, M.M., 1997. Effect of leaf structure and water status on carbon isotope discrimination in field-grown durum wheat. Plant Cell Environ 20, 1484-1494. doi:10.1046/j.1365-3040.1997.d01-43.x

Badal, E., Bernabeu Aubán, J., Vernet, J.L., 1994. Vegetation changes and human action from the Neolithic to the Bronze Age (7000-4000 B.P.) in Alicante, Spain, based on charcoal analysis. Vegetation History and Archaeobotany 3, 155-166.

Bankes, S.C., Lempert, R., Popper, S., 2002. Making Computational Social Science Effective: Epistemology, Methodology, and Technology. Social Science Computer Review 20, 377-388.

Banning, E.B., 2010. Houses, households, and changing society in the Late Neolithic and Chalcolithic of the Southern Levant. Paleorient 36, 46-87.

Banning, E.B., 2007. Wadi Rabah and Related Assemblages in the Southern Levant: Interpreting the Radiocarbon Evidence. paleo 33, 77-101. doi:10.3406/paleo.2007.5208

Banning, E.B., 1996. Flinty Furlongs: The Settlement History of Wadi Ziqlab, Jordan. Ms. on file in the Department of Anthropology, University of Toronto, Canada., Toronto.

Barton, C.M., Ullah, I., Heimsath, A., 2015. How to Make a Barranco: Modeling Erosion and Land-Use in Mediterranean Landscapes. Land 4, 578-606. doi:10.3390/land4030578

Barton, C.M., Ullah, I.I.T., Bergin, S., 2010a. Land use, water and Mediterranean landscapes: modelling long-term dynamics of complex socio-ecological systems. Philosophical Transactions of the Royal Society A: Mathematical, Physical and Engineering Sciences 368, 5275 -5297. doi:10.1098/rsta.2010.0193

Barton, C.M., Ullah, I.I.T., Bergin, S.M., Mitasova, H., Sarjoughian, H., 2012. Looking for the future in the past: long-term change in socioecological systems. Ecological Modelling 241, 42-53. doi:10.1016/j.ecolmodel.2012.02.010

Barton, C.M., Ullah, I.I.T., Mitasova, H., 2010b. Computational modeling and Neolithic socioecological dynamics: a case study from southwest Asia. American Antiquity 75, 364-386.

Bellwood, P., Oxenham, M., 2008. The Expansions of Farming Societies and the Role of the Neolithic Demographic Transition, in: Bocquet-Appel, J.-P., Bar-Yosef, O. (Eds.), The Neolithic Demographic Transition and Its Consequences. Springer Netherlands, pp. 13-34.

Bernabeu Auban, J., Molina Balaguer, L., Orozco Köhler, T., Díaz Castillo, A., Barton, C.M., 2008. Early neolithic at the Serpis Valley, Alicante, Spain, in: Diniz, M. (Ed.), The Early Neolithic in the Iberian Peninsula. Regional and Transregional Components. Proceedings of the XV World Congress (Lisbon, 2006), International Series. BAR, Oxford, pp. 53-59.

Bernabeu Auban, J., Orozco Köhler, T., Diez Castillo, A., Gomez Puche, M., 2003. Mas d'Is (Penàguila, Alicante): aldeas y recintos monumentales del Neolítico Antiguo en el Valle del Serpis. Trabajos de Prehistoria 60, 39-59.

Bintliff, J., 2002. Time, process and catastrophism in the study of Mediterranean alluvial history: a review. World Archaeology 33, 417-435.

Bocquet-Appel, J.-P., 2009. The Demographic Impact of the Agricultural System in Human History. Current Anthropology 50, 657-660. doi:10.1086/605552

Bonet, A., 2004. Secondary succession of semi-arid Mediterranean old-fields in south-eastern Spain: insights for conservation and restoration of degraded lands. Journal of arid environments 56, $213-$ 233.

Bonet, A., Pausas, J.G., 2007. Old field dynamics on the dry side of the Mediterranean Basin: patterns and processes in semiarid SE Spain, in: Cramer, V.A., Hobbs, R.J. (Eds.), Old Fields: Dynamics and Restoration of Abandoned Farmland. Island Press, pp. 247-264. 
Boyd, R., Richerson, P.J., 1985. Culture and the evolutionary process. The University of Chicago Press, Chicago.

Braconnot, P., Harrison, S.P., Kageyama, M., Bartlein, P.J., Masson-Delmotte, V., Abe-Ouchi, A., OttoBliesner, B., Zhao, Y., 2012. Evaluation of climate models using palaeoclimatic data. Nature Clim. Change 2, 417-424. doi:10.1038/nclimate1456

Braidwood, L.S., Braidwood, R.J., Howe, B., Reed, C., 1983. Prehistoric Archaeology along the Zagros Flanks, University of Chicago Oriental Institute publications. The Oriental Institute of the University of Chicago, Chicago, Ill.

Carrión, J.S., Fernández, S., González-Sampériz, P., Gil-Romera, G., Badal, E., Carrión-Marco, Y., LópezMerino, L., López-Sáez, J.A., Fierro, E., Burjachs, F., 2010. Expected trends and surprises in the Lateglacial and Holocene vegetation history of the Iberian Peninsula and Balearic Islands. Review of Palaeobotany and Palynology 162, 458-475. doi:10.1016/j.revpalbo.2009.12.007

Clevis, Q., Tucker, G.E., Lock, G., Lancaster, S.T., Gasparini, N., Desitter, A., Bras, R.L., 2006. Geoarchaeological simulation of meandering river deposits and settlement distributions: A threedimensional approach. Geoarchaeology 21, 843-874.

Corbeels, M., Shiferaw, A., Haile, M., 2000. Farmers' knowledge of soil fertility and local management strategies in Tigray, Ethiopia, Managing Africa's Soils. Russell Press, Nottingham.

Davis, P.K., Anderson, R.H., 2004. Improving the Composability of DoD Models and Simulations. The Journal of Defense Modeling and Simulation: Applications, Methodology, Technology 1, 5-17. doi: $10.1177 / 154851290400100101$

Dawson, T.P., Rounsevell, M.D.A., Kluvánková-Oravská, T., Chobotová, V., Stirling, A., 2010. Dynamic properties of complex adaptive ecosystems: implications for the sustainability of service provision. Biodivers Conserv 19, 2843-2853. doi:10.1007/s10531-010-9892-z

Elliott, M., Fisher, C.T., Nelson, B.A., Molina Garza, R.S., Collins, S.K., Pearsall, D.M., 2010. Climate, agriculture, and cycles of human occupation over the last $4000 \mathrm{yr}$ in southern Zacatecas, Mexico. Quaternary Research 74, 26-35. doi:10.1016/j.yqres.2010.04.001

Flannery, K., 1986. Guilá Naquitz: Archaic Foraging \& Early Agriculture in Oaxaca. Academic Press, New York.

Flannery, K.V., 1993. Will the real model please stand up: comments on Saidel's "Round house or square." Journal of Mediterranean Archaeology 6, 109-117.

Foster, G.R., Meyer, L.D., 1971. A closed-form soil erosion equation for upland areas.

Fuller, D.Q., Asouti, E., Purugganan, M., 2012. Cultivation as slow evolutionary entanglement: comparative data on rate and sequence of domestication. Vegetation History and Archaeobotany 21, 131-145. doi:10.1007/s00334-011-0329-8

Gholami, S., Sarjoughian, H.S., Godding, G.W., Peters, D.R., Chang, V., 2014. Developing composed simulation and optimization models using actual supply-demand network datasets, in: Simulation Conference (WSC), 2014 Winter. Presented at the Simulation Conference (WSC), 2014 Winter, pp. 2510-2521. doi:10.1109/WSC.2014.7020095

Gibbon, D., 1981. Rainfed farming systems in the Mediterranean region. Plant Soil 58, 59-80. doi:10.1007/BF02180049

Granger, D.E., Lifton, N.A., Willenbring, J.K., 2013. A cosmic trip: 25 years of cosmogenic nuclides in geology. Geological Society of America Bulletin 125, 1379-1402. doi:10.1130/B30774.1

Guerrero, E., Naji, S., Bocquet-Appel, J.-P., 2008. The Signal of the Neolithic Demographic Transition in the Levant, in: Bocquet-Appel, J.-P., Bar-Yosef, O. (Eds.), The Neolithic Demographic Transition and Its Consequences. Springer Netherlands, pp. 57-80.

Gutiérrez, Á.G., Schnabel, S., Contador, F.L., 2009. Gully erosion, land use and topographical thresholds during the last 60 years in a small rangeland catchment in SW Spain. Land Degrad. Dev. 20, 535550. doi:10.1002/ldr.931

Henrich, N., Henrich, J.P., 2007. Why humans cooperate: A cultural and evolutionary explanation. Oxford University Press, USA. 
Hillman, G., 1973. Agricultural Productivity and Past Population Potential at Aşvan: An Exercise in the Calculation of Carrying Capacities. Anatolian Studies 23, 225-240.

Hirata, M., Fujita, H., Miyazaki, A., 1998. Changes in grazing areas and feed resources in a dry area of north-eastern Syria. Journal of Arid Environments 40, 319-329. doi:10.1006/jare.1998.0440

Hooke, J.M., 2006. Human impacts on fluvial systems in the Mediterranean region. Geomorphology, 37th Binghamton Geomorphology Symposium The Human Role in Changing Fluvial Systems 79, 311-335. doi:10.1016/j.geomorph.2006.06.036

Kamp, K.A., 2000. From village to tell: household ethnoarchaeology in Syria. Near Eastern Archaeology 63, 84-93. doi:10.2307/3210745

Kamp, K.A., 1987. Affluence and Image: Ethnoarchaeology in a Syrian Village. Journal of Field Archaeology 14, 283-296. doi:10.2307/530085

Kelly Letcher, R.A., Jakeman, A.J., Barreteau, O., Borsuk, M.E., ElSawah, S., Hamilton, S.H., Henriksen, H.J., Kuikka, S., Maier, H.R., Rizzoli, A.E., van Delden, H., Voinov, A.A., 2013. Selecting among five common modelling approaches for integrated environmental assessment and management. Environmental Modelling \& Software 47, 159-181. doi:10.1016/j.envsoft.2013.05.005

Khresat, S.A., Al- Bakri, J., Al- Tahhan, R., 2008. Impacts of land use/cover change on soil properties in the Mediterranean region of northwestern Jordan. Land Degradation \& Development 19, 397 407. doi:10.1002/ldr.847

Khresat, S.A., Rawajfih, Z., Mohammad, M., 1998. Land degradation in north-western Jordan: causes and processes. Journal of Arid Environments 39, 623-629. doi:10.1006/jare.1998.0385

Kim, S., Sarjoughian, H.S., Elamvazhuthi, V., 2009. DEVS-Suite: A simulator for visual experimentation and behavior monitoring, in: High Performance Computing and Simulation Symposium, Proceedings of the Spring Simulation Conference. ACM Press, p. 161.

Kohler, T.A., van der Leeuw, S.E., 2007. Historical Socionatural Systems and Models, in: The ModelBased Archaeology of Socionatural Systems. School for Advanced Research Press, Santa Fe, NM, pp. 1-12.

Kramer, C., 1982. Village Ethnoarchaeology: Rural Iran in Archaeological Perspective. Academic Press, New York.

Kramer, C., 1980. Estimating prehistoric populations: An ethnoarchaeological approach, in: L'Archeologie de L'Iraq Du Debut de L'epoque Neolithique a 333 Avant Notre Ere, Colloque Internationaux Du Centre National de La Recherche Scientifique. Editions du Centre Nacional du Recherche Scientifique, Paris, pp. 315-334.

Kuijt, I., 2000. People and Space in Early Agricultural Villages: Exploring Daily Lives, Community Size, and Architecture in the Late Pre-Pottery Neolithic. Journal of Anthropological Archaeology 19, 75-102. doi:10.1006/jaar.1999.0352

Marzolff, I., Ries, J.B., Poesen, J., 2011. Short-term versus medium-term monitoring for detecting gullyerosion variability in a Mediterranean environment. Earth Surf. Process. Landforms 36, 16041623. doi:10.1002/esp.2172

Mayer, G.R., Sarjoughian, H.S., 2009. Composable Cellular Automata. SIMULATION 85, 735-749. doi: 10.1177/0037549709106341

Mayer, G.R., Sarjoughian, H.S., Allen, E.K., Falconer, S.E., Barton, C.M., 2006. Simulation modeling for human community and agricultural landuse, in: Agent-Directed Simulation, Proceedings of the Agent-Directed Simulation Multi-Conference, Huntsville, Alabama. Society for Computer Simulation International, San Diego, CA, pp. 65-72.

McClure, S.B., Barton, C.M., Jochim, M.A., 2009. Human behavioral ecology and climate change during the transition to agriculture in Valencia, eastern Spain. Journal of Anthropological Research 65.

Miller, J.H., Page, S.E., 2007. Complex adaptive systems: an introduction to computational models of social life. Princeton University Press, Princeton, N.J.

Mitas, L., Mitasova, H., 1998. Distributed soil erosion simulation for effective erosion prevention. Water Resources Research 34, 505-516. 
Mitasova, H., Barton, C.M., Ullah, I.I.T., Hofierka, J., Harmon, R.S., 2013. GIS-based soil erosion modeling, in: Shroder, J., Bishop, M. (Eds.), Treatise in Geomorphology: Vol. 3 Remote Sensing and GI Science in Geomorphology. Academic Press, San Diego, CA, pp. 228-258.

Mitasova, H., Hofierka, J., Zlocha, M., Iverson, R., 1996. Modeling topographic potential for erosion and deposition using GIS.

Moore, I.D., Burch, G.J., 1986. Physical Basis of the Length-slope Factor in the Universal Soil Loss Equation. Soil Sci Soc Am J 50, 1294-1298.

Neteler, M., Bowman, M.H., Landa, M., Metz, M., 2012. GRASS GIS: A multi-purpose open source GIS. Environmental Modelling \& Software. doi:10.1016/j.envsoft.2011.11.014

Neteler, M., Mitasova, H., 2008. Open Source GIS: a GRASS GIS Approach, 3rd Edition. Springer, New York.

Nogueras, P., Burjachs, F., Gallart, F., Puigdefàbregas, J., 2000. Recent gully erosion in the El Cautivo badlands (Tabernas, SE Spain). CATENA 40, 203-215. doi:10.1016/S0341-8162(99)00048-X

North, M.J., Collier, N.T., Ozik, J., Tatara, E.R., Macal, C.M., Bragen, M., Sydelko, P., 2013. Complex adaptive systems modeling with Repast Simphony. Complex Adaptive Systems Modeling 1, 3. doi:10.1186/2194-3206-1-3

North, M.J., Tatara, E., Collier, N.T., Ozik, J., 2007. Visual agent-based model development with repast simphony. Tech. rep., Argonne National Laboratory.

Nyerges, A.E., 1980. Traditional pastoralism: an evolutionary perspective. Expedition 22, 36-41.

Pausas, J.G., 2006. Simulating Mediterranean landscape pattern and vegetation dynamics under different fire regimes. Plant Ecology 187, 249-259. doi:10.1007/s11258-006-9138-z

Pausas, J.G., 1999. Response of plant functional types to changes in the fire regime in Mediterranean ecosystems: A simulation approach. Journal of Vegetation Science 10, 717-722. doi:10.2307/3237086

Pechenkina, E.A., Benfer, R.A., Zhijun, W., 2002. Diet and health changes at the end of the Chinese neolithic: The Yangshao/Longshan transition in Shaanxi province. Am. J. Phys. Anthropol. 117, 15-36. doi:10.1002/ajpa.10014

Quintero, L.A., Wilke, P.J., Rollefson, G.O., 2004. Highland Towns and Desert Settlements: Origins of Nomadic Pastoralism in the Jordanian Neolithic, in: Central Settlements in Neolithic Jordan. ex oriente, Berlin, pp. 201-213.

Rendell, L., Boyd, R., Cownden, D., Enquist, M., Eriksson, K., Feldman, M.W., Fogarty, L., Ghirlanda, S., Lillicrap, T., Laland, K.N., 2010. Why Copy Others? Insights from the Social Learning Strategies Tournament. Science 328, 208-213. doi:10.1126/science.1184719

Rindos, D., 1980. Symbiosis, instability, and the origins and spread of agriculture: a new model. Current Anthropology 21, 751-772.

Rosen, S.A., 2008. Desert pastoral nomadism in the Longue Durée: A case study from the Negev and the southern Levantine deserts, in: The Archaeology of Mobility: Old World and New World Nomadism. Cotsen Institute Of Archaeology, University Of California, Los Angeles, pp. 115140.

Rounsevell, M.D.A., Arneth, A., Alexander, P., Brown, D.G., de Noblet-Ducoudré, N., Ellis, E., Finnigan, J., Galvin, K., Grigg, N., Harman, I., Lennox, J., Magliocca, N., Parker, D., O’Neill, B.C., Verburg, P.H., Young, O., 2014. Towards decision-based global land use models for improved understanding of the Earth system. Earth Syst. Dynam. 5, 117-137. doi:10.5194/esd-5-117-2014

Sarjoughian, H.S., 2006. Model Composability, in: Winter Simulation Conference,Monterey, CA 2006. Presented at the Winter Simulation Conference,Monterey, CA 2006, ACM Digital Library, pp. 149-158.

Sarjoughian, H.S., Meyer, G.R., Ullah, I.I., Barton, C.M., 2015. Managing Hybrid Model Composition Complexity: Human-Environment Simulation Models, in: Yilmaz, L. (Ed.), Concepts and Methodologies for Modeling and Simulation, Simulation Foundations, Methods and Applications. Springer International Publishing, pp. 107-134. 
Sarjoughian, H., Smith, J., Godding, G., Muqsith, M., 2013. Model composability and execution across simulation, optimization, and forecast models, in: Proceedings of the Symposium on Theory of Modeling \& Simulation-DEVS Integrative M\&S Symposium. Society for Computer Simulation International, p. 30.

Shennan, S., Downey, S.S., Timpson, A., Edinborough, K., Colledge, S., Kerig, T., Manning, K., Thomas, M.G., 2013. Regional population collapse followed initial agriculture booms in mid-Holocene Europe. Nature Communications 4. doi:10.1038/ncomms3486

Sherratt, A., 1983. The secondary exploitation of animals in the Old World. World Archaeology 15, 90104.

Simmons, A.H., 2007. The neolithic revolution in the Near East : transforming the human landscape. University of Arizona Press, Tucson.

Soto-Berelov, M., 2011. Vegetation Modeling of Holocene Landscapes in the Southern Levant (doctoral disseration). Arizona State University, Tempe, AZ.

Stuth, J.W., Sheffield, W.J., 1991. Determining Carrying Capacity for Combinations of Livestock, Whitetailed Deer and Exotic Ungulates, in: Wildlife Management Handbook. Texas A\&M University Department of Wildlife and Fisheries Sciences, College Station, pp. 5-12.

Thomson, E.F., 1987. Feeding systems and sheep husbandry in the barley belt of Syria. ICARDA, Aleppo.

Thomson, E.F., Bahhady, F., Thermanini, A., Mokbel, M., 1986. Availability of home-produced wheat, milk products and meat to sheep-owing families at the cultivated margin of the NW Syrian steppe. Ecology of Food and Nutrition 19, 113-21.

Tucker, G.E., Bradley, D.N., 2010. Trouble with diffusion: Reassessing hillslope erosion laws with a particle-based model. J. Geophys. Res. 115, F00A10. doi:10.1029/2009JF001264

Twiss, K.C., 2007. The Neolithic of the southern Levant. Evolutionary anthropology 1, 24-35.

Ullah, I.I.T., 2013. The Consequences of Human land-use Strategies During the PPNB-LN Transition: A Simulation Modeling Approach (PhD Dissertation). Arizona State University.

Ullah, I.I.T., 2011. A GIS method for assessing the zone of human-environmental impact around archaeological sites: a test case from the Late Neolithic of Wadi Ziqlâb, Jordan. Journal of Archaeological Science 38, 623-632. doi:10.1016/j.jas.2010.10.015

Ullah, I.I.T., Kuijt, I., Freeman, J., 2015. Toward a theory of punctuated subsistence change. Proceedings of the National Academy of Sciences 201503628. doi:10.1073/pnas.1503628112

van der Leeuw, S.E., 2004. Why model? Cybernetics and Systems: An International Journal 35, 117-128. doi:10.1080/01969720490426803

Verburg, P.H., Dearing, J.A., Dyke, J., van der Leeuw, S.E., Seitzinger, S., Steffen, W., Syvitski, J.P., in press. Methods and Approaches to Modelling the Anthropocene. Global Environmental Change.

Vigne, J.-D., 2011. The origins of animal domestication and husbandry: A major change in the history of humanity and the biosphere. Comptes Rendus Biologies 334, 171-181. doi:10.1016/j.crvi.2010.12.009

Watson, P.J., 1979. Archaeological ethnography in western Iran. Published for the Wenner-Gren Foundation for Anthropological Research, inc.[by] University of Arizona Press. 


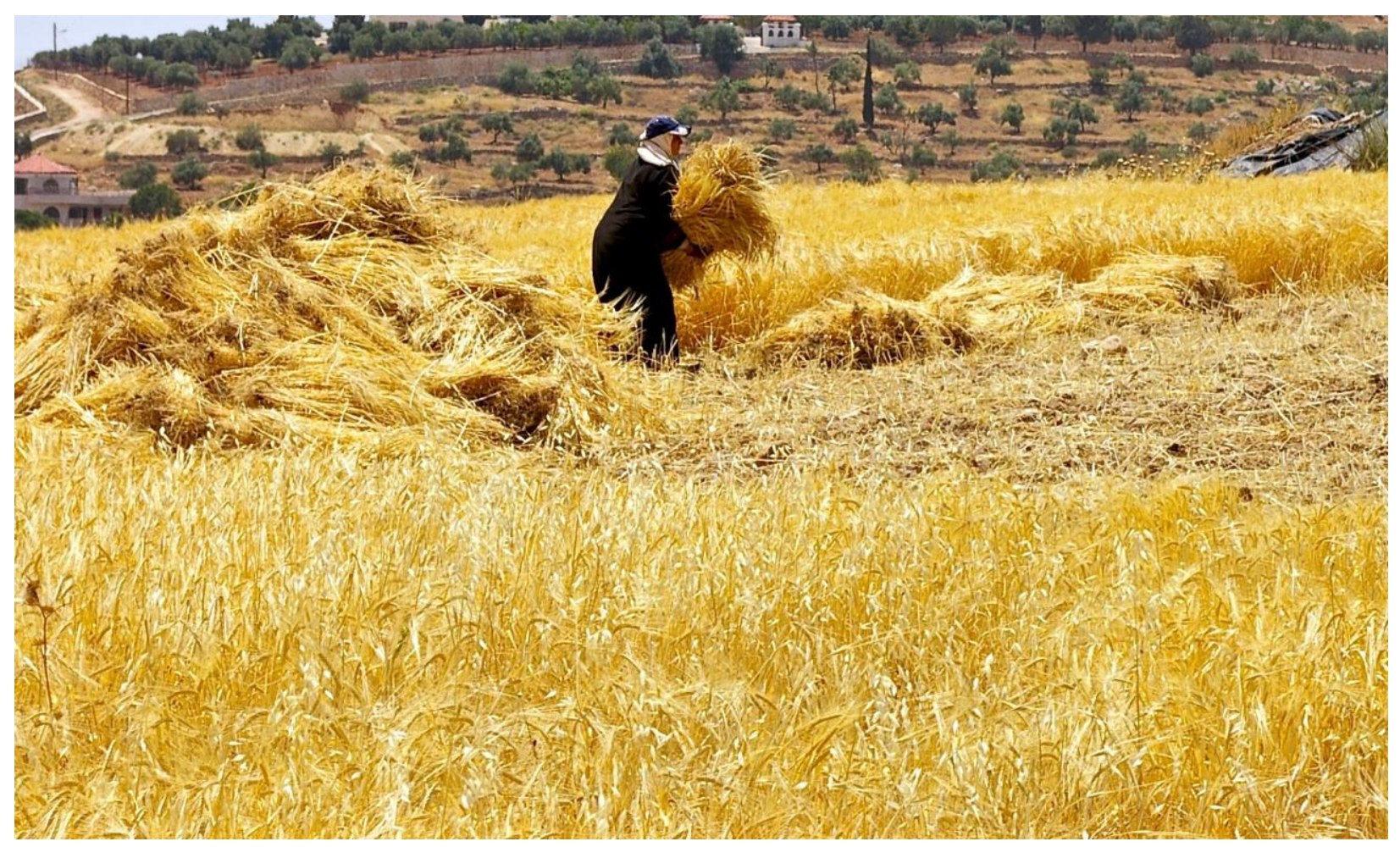




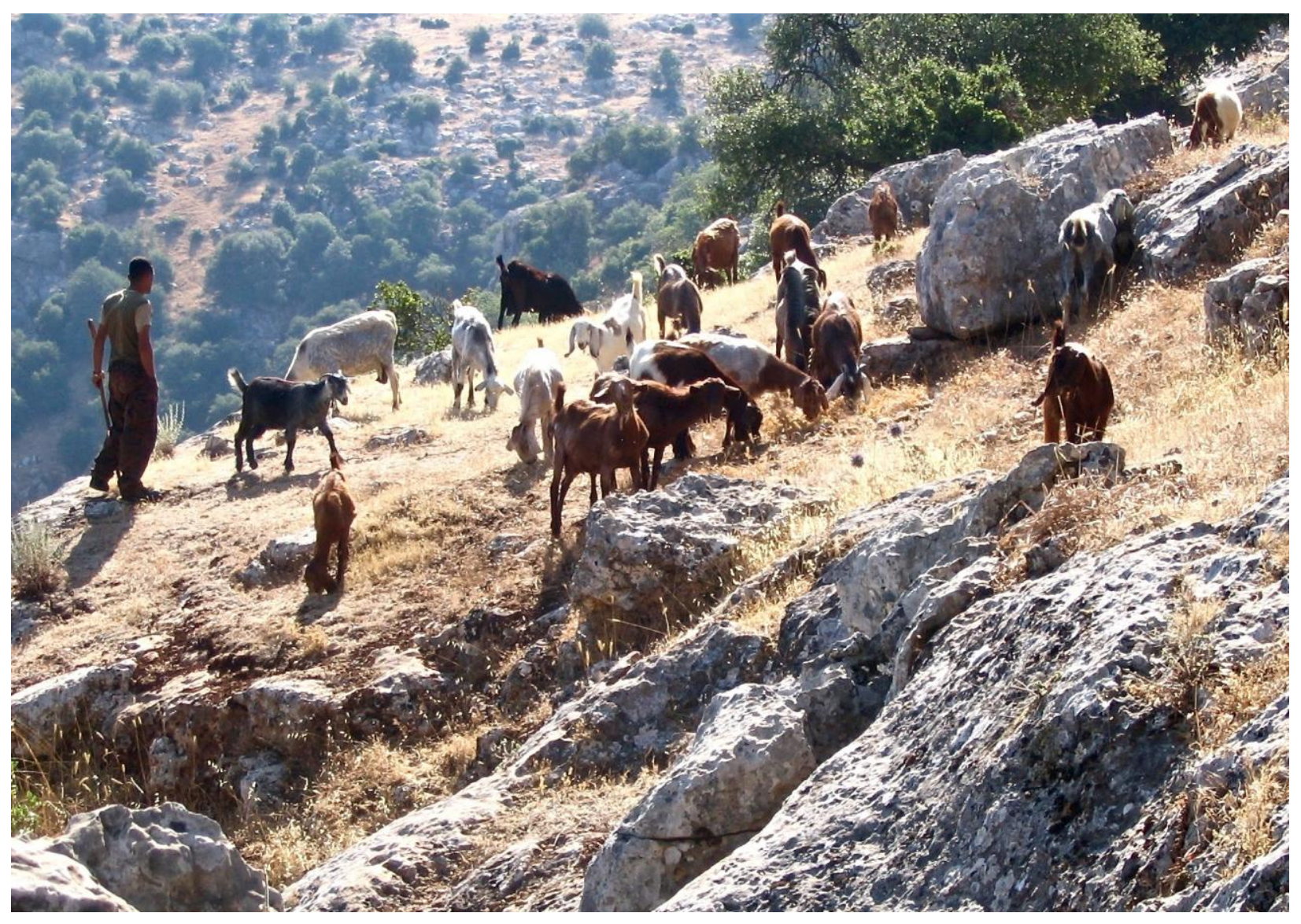




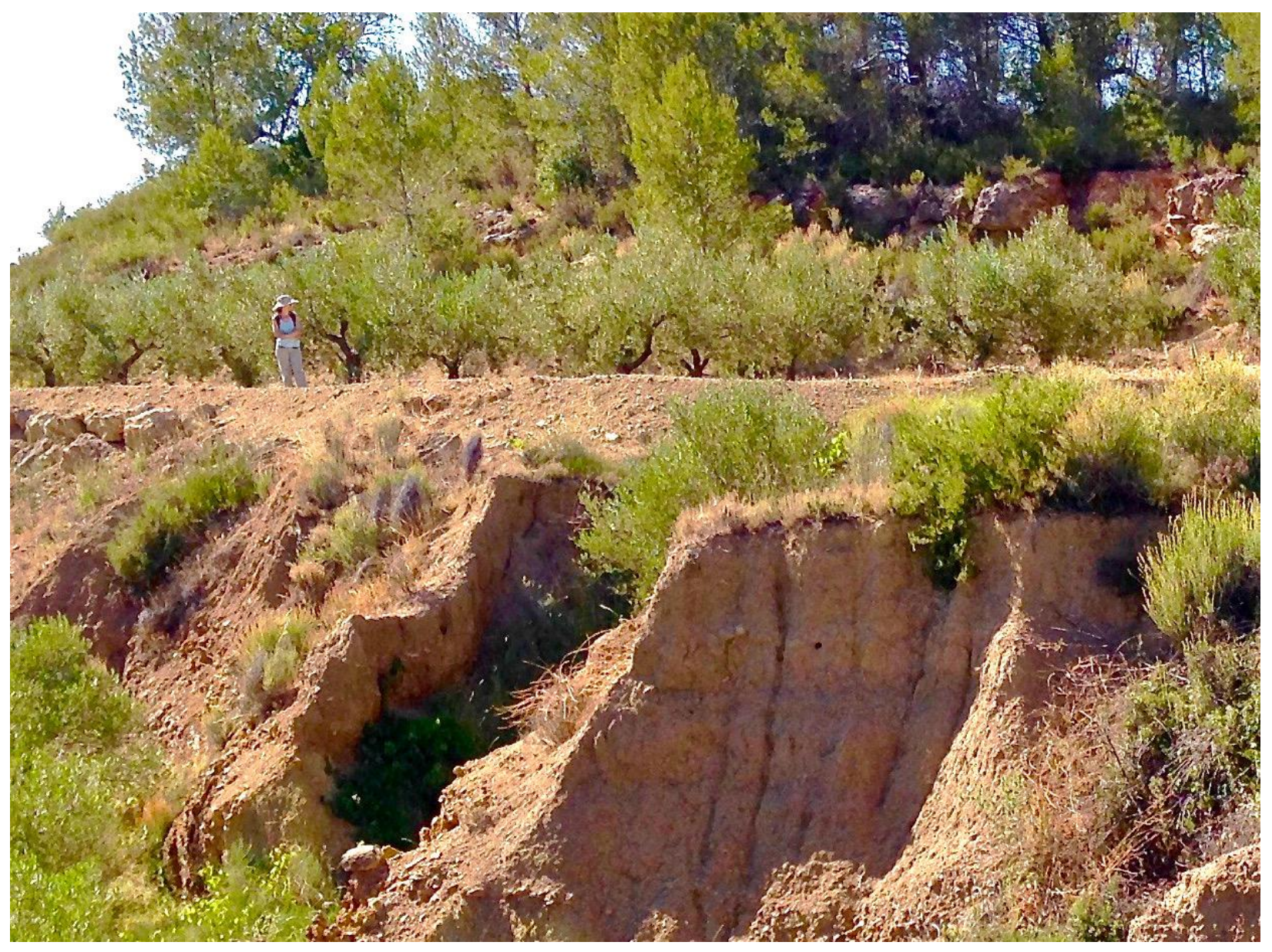




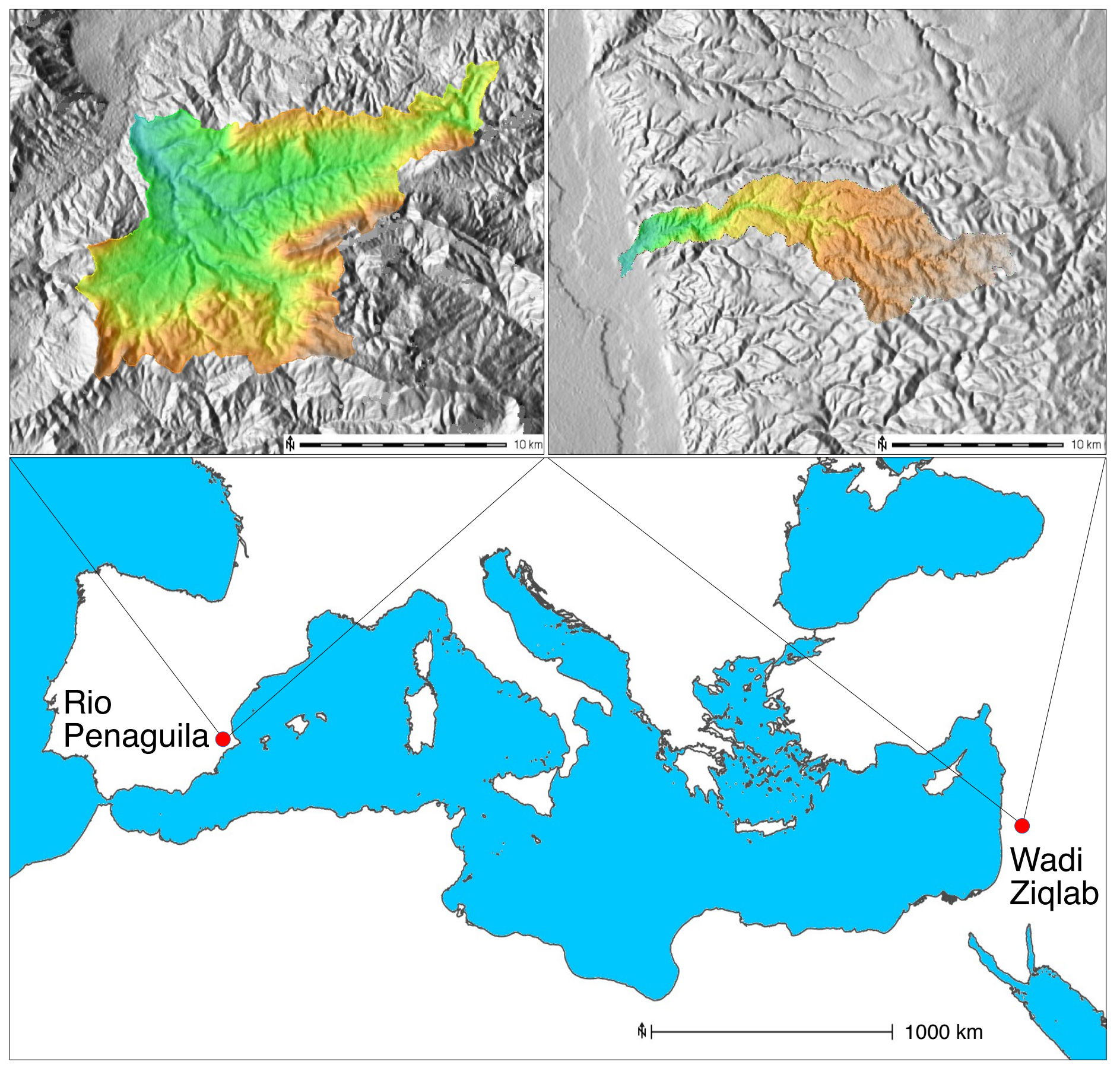



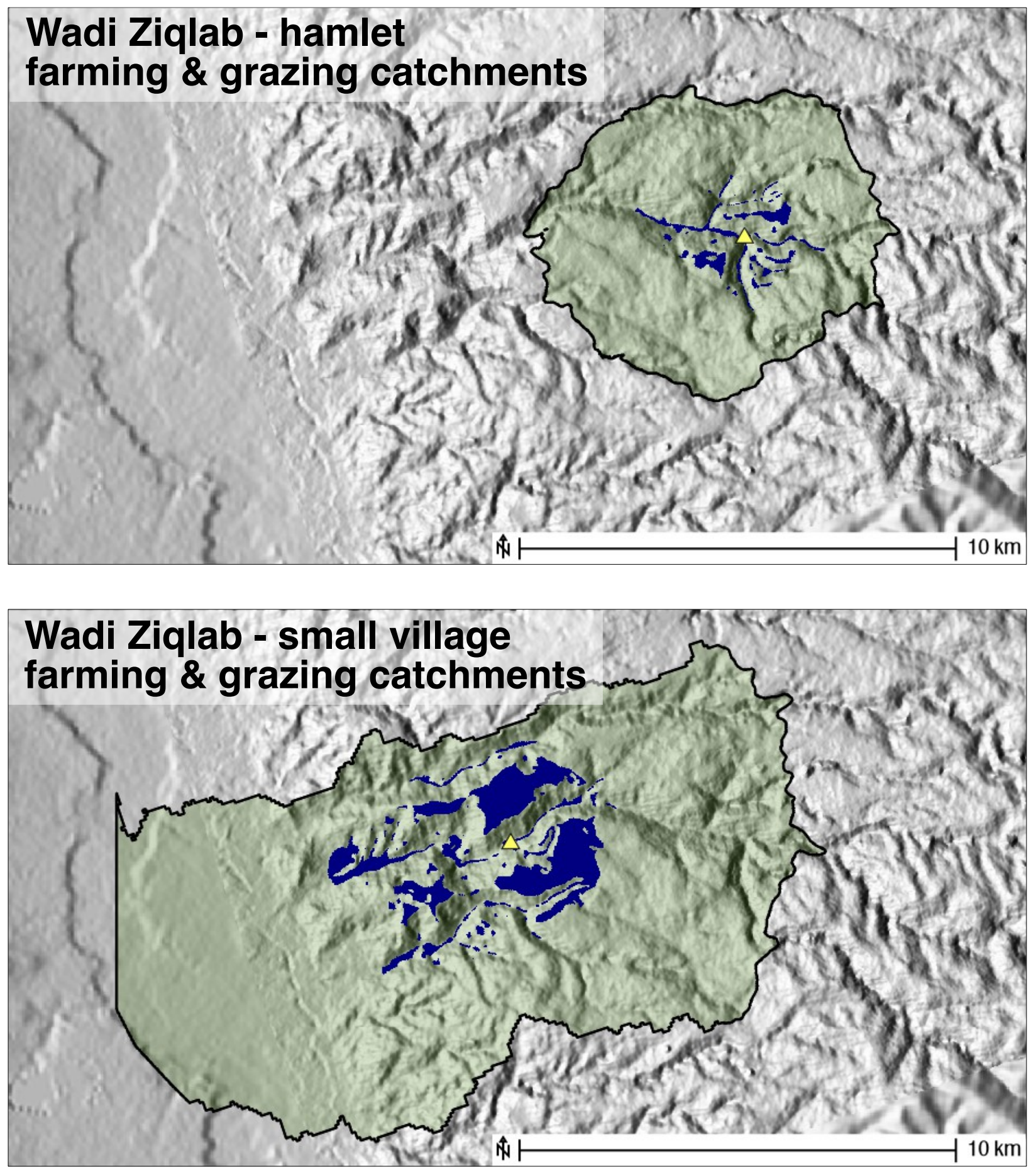


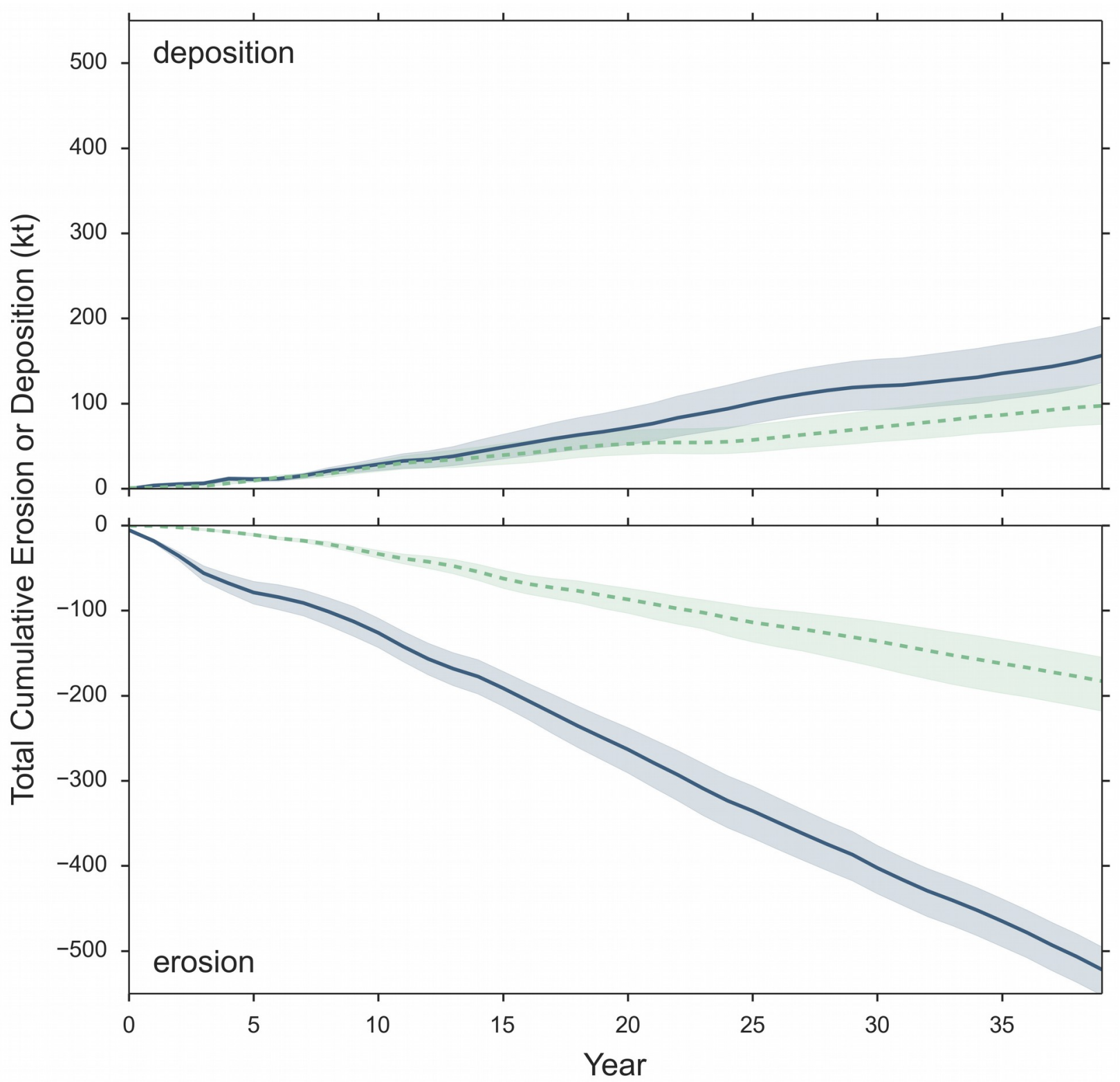

_ Small Village $\quad=-$ Farming Hamlet 


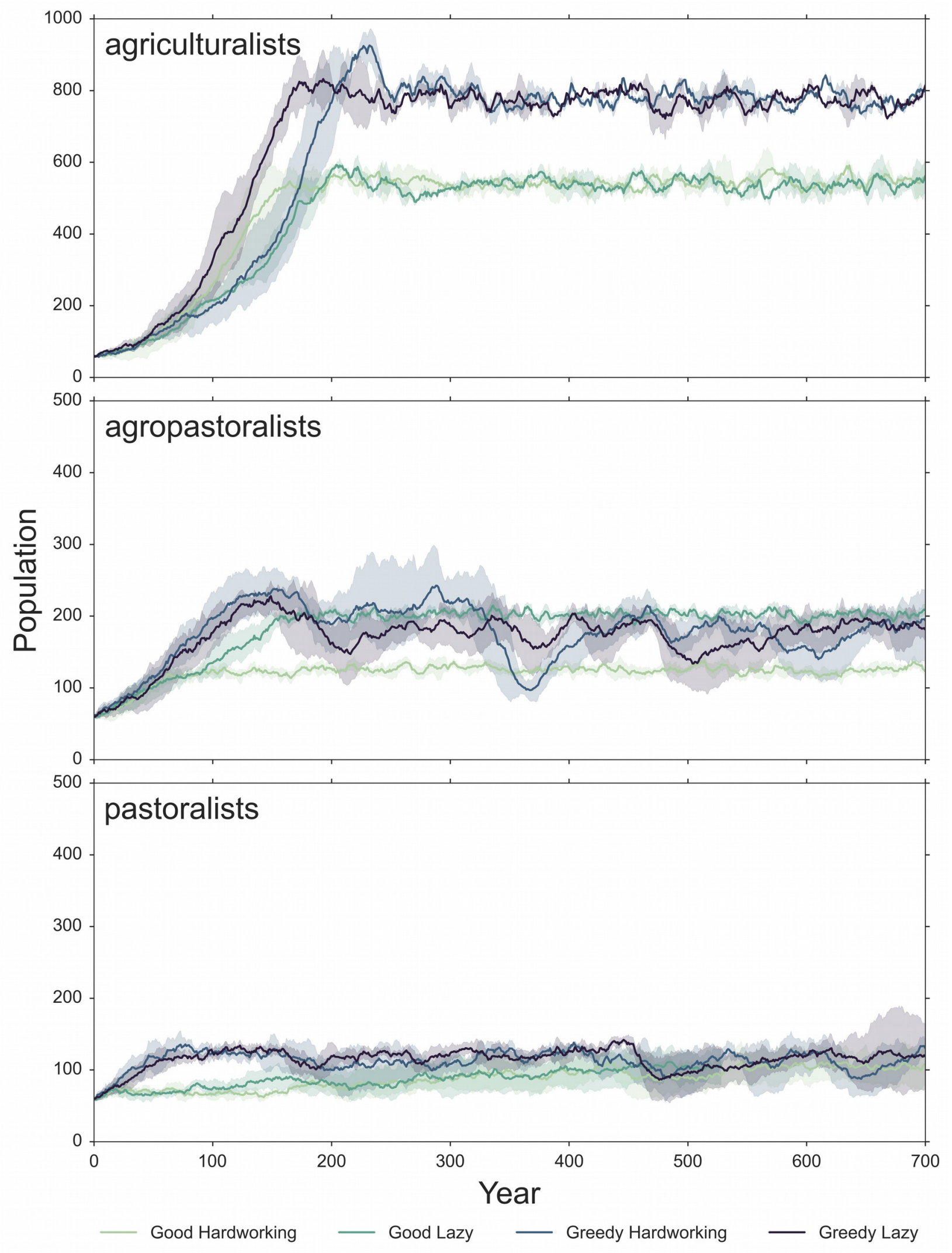




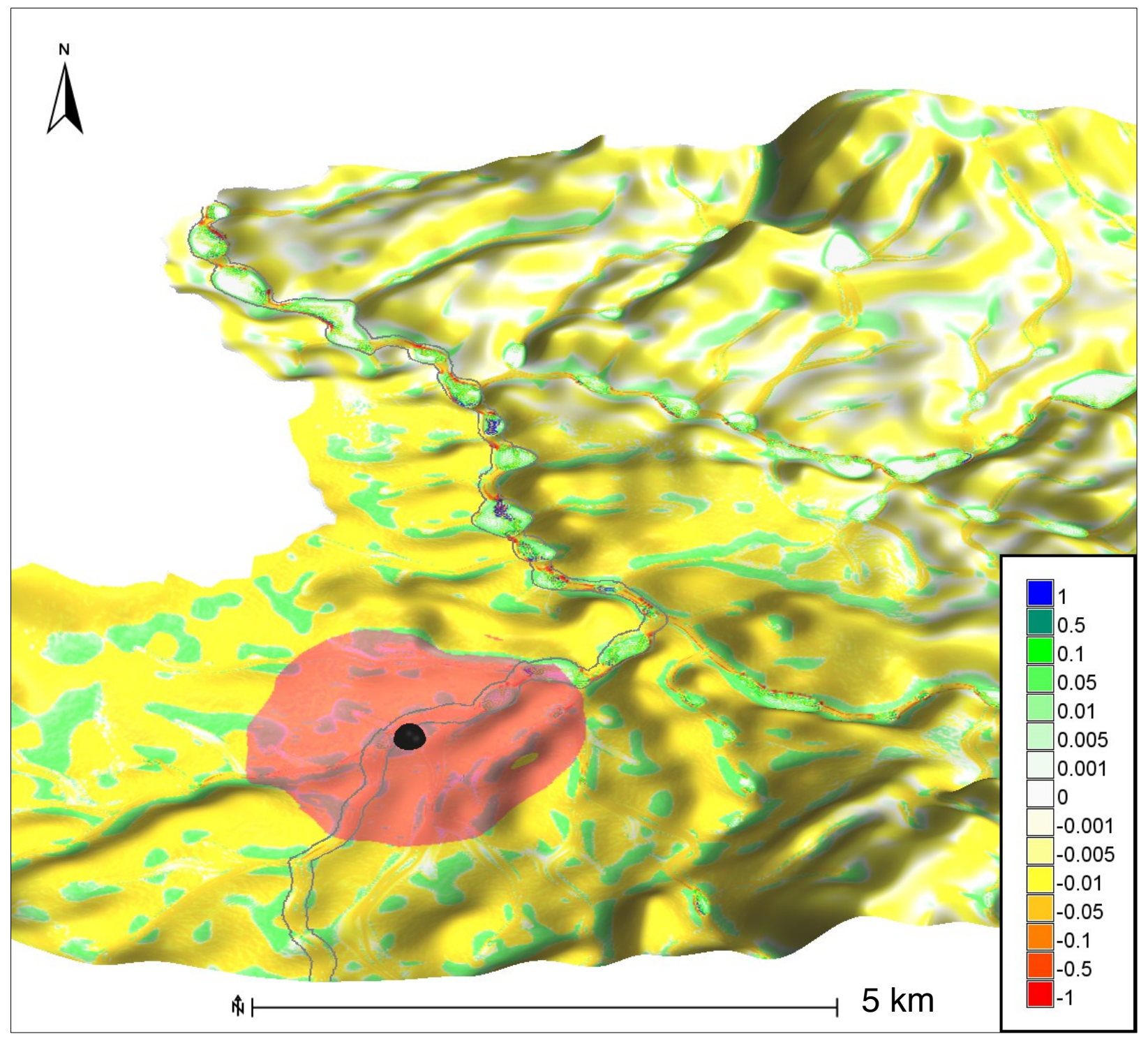



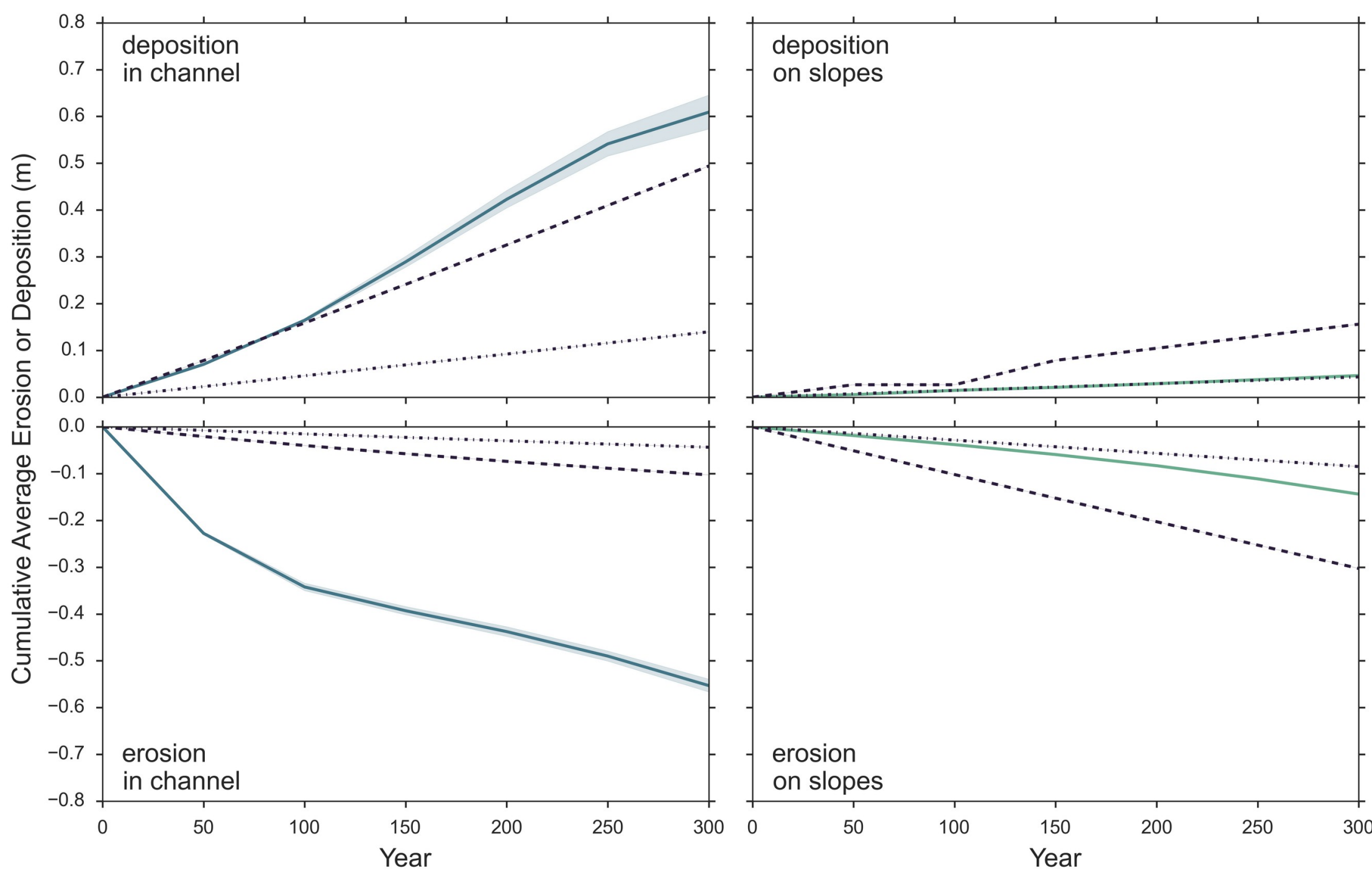

_ Main Barranco

_ Hillslopes

- - - Control Model, Grassland

.... Control Model, Woodland 
Modeling Long-Term Dynamics of Coupled Natural and Human Landscapes

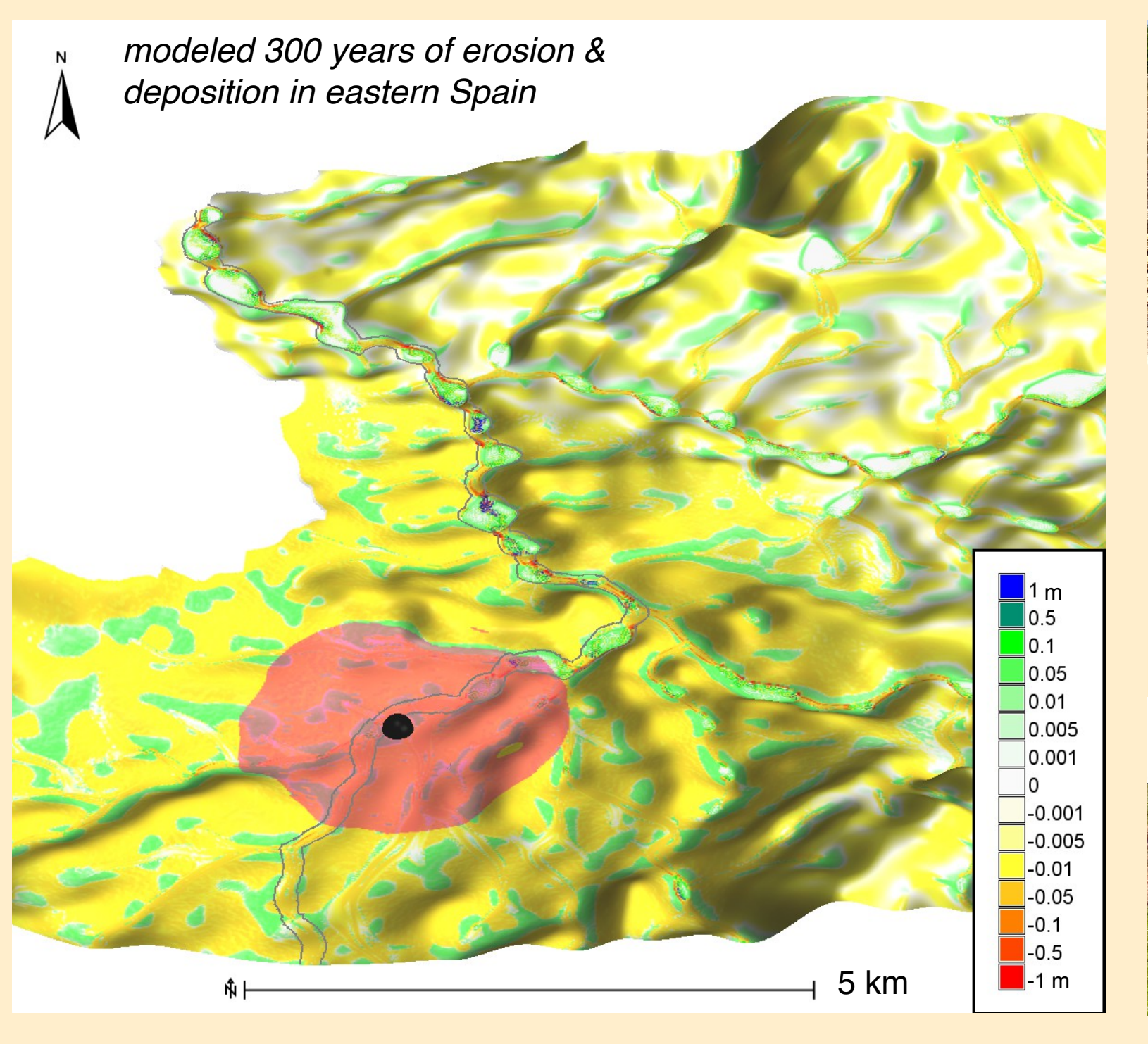

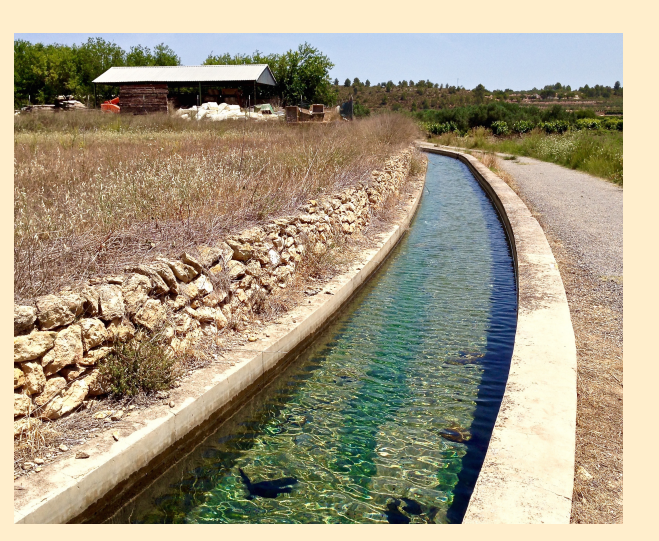

feedbacks in biophysical systems

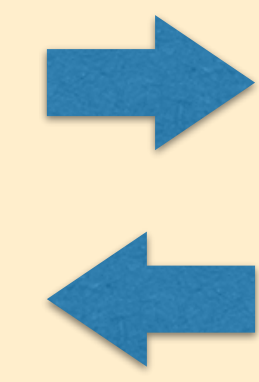

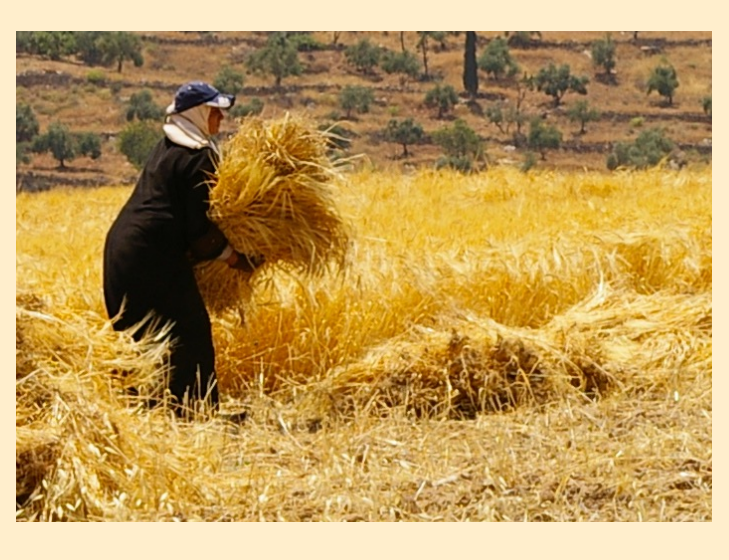

feedbacks in social systems
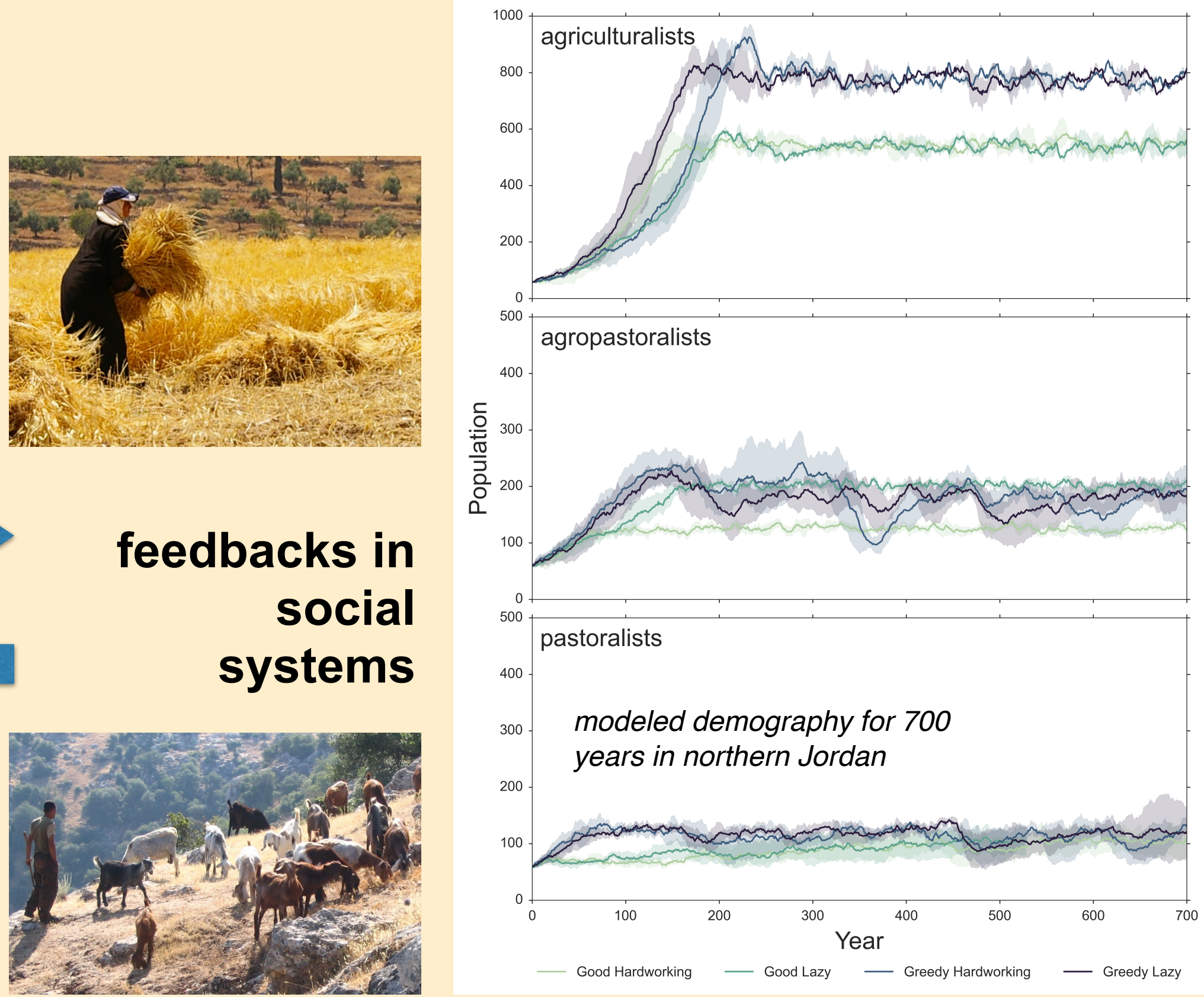